\title{
Analisis Ketidaksinambungan Dokumentasi Perencanaan Asuhan Keperawatan : Metode Ishikawa
}

\author{
Purnama Christina $^{1}$, Agustin Indracahyani' ${ }^{2}$ Aat Yatnikasaria $^{3}$ \\ 1.Mahasiswa Program Studi Magister Ilmu Keperawatan FIK UI, email \\ cepur.poenya@gmail.com \\ 2.DKKD Fakultas Ilmu Keperawatan Universitas Indonesia Depok \\ 3.Komite Keperawatan Rumah Sakit Anak Bunda Harapan Kita Jakarta
}

\begin{abstract}
Abstrak
Perencanaan asuhan keperawatan merupakan kunci dari continuity of care.Dokumentasi perencanaan asuhan keperawatan yang tidak saling berkesinambungan dalam rekam medis berdampak pada kualitas asuhan pasien. Tujuan studi ini adalah menganalisis penyebab fenomena ketidaksinambungan tersebut sehingga dapat memberikan rekomendasi untuk perbaikan bagi pelayanan asuhan keperawatan. Metode yang digunakan adalah studi kasus dengan pendekatan analisis gap antara kondisi yang terjadi dengan kondisi ideal. Studi ini menganalisis fenomena berdasarkan pendekatan fungsi manajemen keperawatan dan metode Ishikawa. Teknik pengumpulan datanya adalah dengan cara wawancara, observasi dan data sekunder dari studi dokumentasi data rumah sakit. Responden dipilih dengan cara tehnik purposive sampling sejumlah sembilan orang manajer keperawatan. Hasil analisis Ishikawa menemukan penyebab utama adalah lembar POC pada awalnya diberlakukan oleh pokja akreditasi rumah sakit sehingga setelah penilaian akreditasi selesai keberlanjutannya terhambat. Selain itu ditemukan juga masalah lain sepertipengetahuan perawat tentang metode penugasan perawat primer, ketenagaan dan supervisi rekam medis POC yang belum optimal. Kesimpulan dari analisis fungsi manajemen keperawatandiperoleh bahwa fungsi pengarahan dan fungsi pengendalian perlu ditingkatkan agar dokumentasi perencanaan asuhan keperawatan lebih optimal.
\end{abstract}

Keyword: metode ishikawa, perencanaan keperawatan, fungsi manajemen.

\section{Analysis of Discontinuity of Nursing Care Planning Documentation: Ishikawa Method.}

\section{Abstract}

Planning nursing care is the key to continuity of care. Documentation of non-mutually sustainable nursing care planning in medical records has an impact on the qualities of patient care. The purpose of this study is to analyze the causes of the phenomenon of discontinuity so that it can give recommendations for improvement for nursing care services. The method used is a case study with a gap analysis approach between conditions that occur with ideal conditions. This study analyzes phenomena based on nursing management function approach and Ishikawa method. The data collection technique is by interview, observation and secondary data from hospital data documentation studies. Respondents are select by a purposive sampling technique with nine nursing managers. Ishikawa's analysis found that the main cause was that the POC sheet was initially applied by the hospital accreditation working group so that after the accreditation assessment finished the sustainability hampered. In addition, other problems were also 
found such as nurses' knowledge about the primary nurse assignment method, workforce and supervision of POC medical records that were not ideal. Conclusion of analysis of nursing management functions is that the directional function and control function need to improved so that the planning of nursing care is more ideal.

Keyword: ishikawa analysis, management functions, nursing care plan.

\section{Pendahuluan}

Perencanaan asuhan keperawatan khususnya di ruang intensif merupakan kunci dari continuity of care. Idealnya, perencanaan asuhan keperawatan bersifat individualistik dan responsif terhadap kebutuhan unik pasien. Tujuannya adalah menyusun strategi untuk mengatasi hambatan atau masalah pasien. Perawat secara teratur meninjau kemajuan pasien dan merevisi rencana perawatan yang sesuai kebutuhan pasien (Choi \& De Gagne, 2016).

Tanggung jawab Kepala ruang terkait perencanaan asuhan keperawatan (nursing care plan) adalah memastikan bahwa perencanaan yang dibuat perawatsudah sesuai dengan kebutuhan pasien dan terdokumentasi dengan baik. Dokumentasi keperawatan dalam rekam medis pasien dapat menjadi tolak ukur kualitas pelayanan asuhan keperawatan (Gillies, 1994). Dokumentasi keperawatan adalah sesuatu yang tertulis tentang keadaan pasien dan asuhan keperawatan yang telah diberikan, berfungsi sebagai catatan bukti dan validasi bagi perawat yang telah mengerjakan proses keperawatan (Kozier, Erb, Berman, \& Synder, 2016).

Fungsi manajemen keperawatan yang dilakukan oleh Kepala ruangerat kaitannya dengan dokumentasi asuhan keperawatan, hal ini didukung olehhasil penelitian yaitu fungsi pengarahan dari kepala ruangan berupa supervisi dapat meningkatkan kinerja perawat pelaksana dalam pendokumentasian keperawatan (Hastuti, 2014; Wirawan, Novitasari, \& Wijayanti, 2013). Supervisi juga dapat mempengaruhi kepuasan kerja perawat. Penelitianlain juga mengatakan bahwa fungsi manajemen keperawatan berupa supervisi, promosi, regulasi prosedur, dan penghargaan mempengaruhi kepuasan perawat di ruang CCU/Critical Care Unit (Owens, 2014).

Tata kelola perawat manajer dapat meningkatkan empowerment perawat, manajemen diri, memfasilitasi interprofesional dan kepuasan (Cox Sullivan, Norris, Brown, \& Scott, 2017; Heale, Dickieson, Carter, \& Wenghofer, 2014). Perawat manajer juga berperan mengembangkan kebijakan/pedoman dan pelatihan bagi perawat untuk dokumentasi yang efektif (Asamani, Amenorpe, Babanawo, \& Ofei, 2014).

Telusur terbuka terhadap rekam medis di ruang intensif Rumah Sakit Khusus Ibu dan Anak Jakarta ditemukan ketidaksinambungan antara perencanaan asuhan keperawatan dalamlembarPlan of Care (POC) terintegrasi dengan rencana asuhan keperawatan padaflowsheetharian pasien. Perencanaan asuhan keperawatan pada lembar POC dibuat oleh perawat primer sedangkan perencanaan dalam 
flowsheet harian ditulis oleh perawat pelaksana. Oleh sebab itu dilakukan studi kasus manajemen keperawatan untukmencari akar masalah ketidaksinambungan tersebut dan melakukan pemetaan sebagai upaya meningkatkan mutu perencanaan asuhan keperawatan primer. Pembahasan hasil telusur ini akan menganalisis upaya-upaya peningkatkan kualitas POC terintegrasi melalui fungsi manajemen keperawatan.

\section{Metode}

Penulisan ini berupa studi kasus dengan menggunakan metode analisis gap yaitu membandingkan antara kondisi pelayanan keperawatan di rumah sakit khusus ibu dan anak Jakarta dengan kondisi ideal sesuai referensi. Analisis dalam studi kasus inimenggunakan pendekatan fungsi manajemen keperawatan dan metode Ishikawa untuk mencari akar masalah. Responden dipilih dengan cara tehnik purposive samplingsebanyak sembilan orang. Pemilihan dilakukan pada semua level manajer keperawatan rumah sakit mulai dari kepala ruangan, kepala instalasi, kepala bidang keperawatan dan ditambah dengan komite keperawatan. Teknik pengumpulan data melalui metode wawancara, observasi dan data sekunder dari rumah sakit. Instrumen yang digunakan adalah panduan wawancara terstruktur dan lembar checklist observasi berfokus pada fungsi manajemen keperawatan yang disusun berdasarkan referensi dan konsultasi kepakaran. Data observasi juga diperoleh melalui observasi alur penerimaan pasien, alur proses keperawatan di ruang intensif serta alur supervisi manajemen dari Bidang Keperawatan selama enam minggu berturut-turut.

\section{Hasil}

1. Karakteristik perawat Intensive Care Unit (ICU)

Struktur organisasi ruang rawat ICU terdiri dari Kepala ruangan, satu orang Clinical Instructor (CI), tiga orang Perawat Primer (PP), tujuh orang perawat penanggung jawab shift/ketua tim dan 28 orang perawat pelaksana. Ruang ICU tersebut sesuai jadwal bulan september 2018 diketahui ketenagaan perawat klinik (PK) terdiri dari $60 \%$ PK III terlatih ICU; 17,5\% PK II terlatih ICU; 7.5\% PK I terlatih ICU dan 15\% PraPK belum terlatih ICU tetapi sudah pelatihan BHD (Bantuan Hidup Dasar). Jadi total perawat ICU terlatih mencapai $85 \%$.

2. Manajemen Asuhan keperawatan. Metode penugasan yang diterapkan adalah Metode Asuhan Keperawatan Primer (MAKP). Metode ini telah didukung oleh regulasi rumah sakit dan telah terbentuk organisasinya di unit-unit pelayanan rawat inap. Suatu ruang perawatan dipimpin oleh kepala ruangan. Kepala ruangan tidak memiliki wakil, tugas kepala ruangan terkait pelayanan asuhan keperawatan dibantu oleh seorang CI. Kepala ruangan jika sedang tugas luar atau berhalangan hadir, maka tugasnya didelegasikan kepada CI ruangan. Ruang ICUmemiliki tiga orang perawat primer yang dibagi tugas berdasarkan tiga ruangan yaitu ruang MICU (Mother Intensive Care Unit), ICU Anak Level II dan ICU Anak Level III. 
Perawat primer merencanakan asuhan keperawatan berdasarkan analisis data dan Panduan Asuhan Keperawatan (PAK) yang berlaku di rumah sakit pada lembar POC. POC diimplementasikan oleh perawat pelaksana yang kemudian didokumentasikan dalam flowsheet pasien. Hasil observasi ditemukan rencana asuhan keperawatan pada lembar POC belum sesuai denganflowsheetharian pasien, contohnya di POC terdapat hanya 5 masalah asuhan keperawatan, namun padaflowsheetharian dapat ditemukan 10 sampai 12 masalah keperawatan.

Tabel 1. Hasil wawancara dan observasi

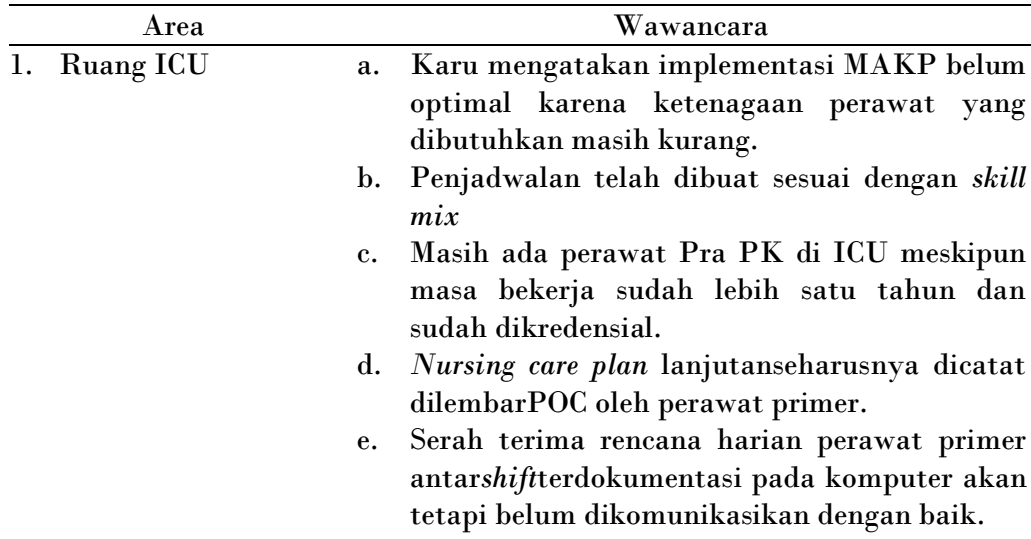

2. Kepala Instalasi Tugas dan wewenang Instalasi lebih kepada ICU

3. Komite Keperawatan

4. Bidang Keperawatan pelayanan dan pengadaan fasilitas sumber daya ICU.

Peran serta Komite Keperawatan terhadap nursing care plan adalah rekomendasi terkait kompetensi dan kewenangan klinis perawat primer dan perawat pelaksana.

a. Supervisi pelaksanaan asuhan keperawatan primer didelegasikan dari Kepala ruang kepada clinical instructor (CI).

b. Evaluasi implementasi MAKP tahun 2018 belum terlaksana

c. Perawat primer mendokumentasi nursing care plan di POC saat awal masuk pasien.

d. Belum ada petujuk tehnik bagaimana pengisian POC terutama mengenai assesmen lanjutan.

e. Form POC berasal dari Pokja ARK saat masa Akreditasi, bukan dari Bidang keperawatan.

f. Nursing care plan pada lembar POC di ruangICU ditentukan minimal lima masalah keperawatandengan syarat harus dilaksanakan secara komprehensif. Namun seringnya dipersepsikan hanya membuat limacare plan saja dilembar POC.

\begin{abstract}
Observasi
Nursing care plan pada lembar POC yang dibuat oleh perawat primer belum sesuai dengan perencanaan didalamflowsheet pasien. Ketidaksinambungan ini mungkin disebabkan oleh :

a. Ratio perawat dan pasien 1:2 dengan kapasitas 14 tempat tidur.

b. Adanya budaya bertukar jaga antar perawat ICU sehingga komposisi ketenagaan kadang tidak seimbang dan menyebabkan fungsi perawat primer terhambat.

c. Perawat ICU masih ada yang Pra PK dan PK I
\end{abstract}

Instalasi tidak berfokus pada Asuhan Keperawatan.

Proses kredensial oleh Subkomite kredensial telah berjalan sesuai dengan perencanaan komite keperawatan.

a. Ada kegiatan supervisi rekam medis terbuka dari Bidang Keperawatan.

b. Telusur rekam medis lembar POC masih menilai sebatas ada atau tidak saja. Kualitas POC dan kesinambungan POC selama pasien dirawat belum terlaksana. 
3. Fungsi Manajemen Keperawatan

Perencanaan Bidang Keperawatan terkait metode penugasan asuhan keperawatan sudah berjalan sangat baik. Hal ini dibuktikan dengan adanya regulasi Metode Asuhan Keperawatan Primer (MAKP), Panduan MAKP dan Panduan Asuhan Keperawatan (PAK) yang berlaku di Rumah Sakit. Organisasi MAKP juga sudah terbentuk disetiap ruang ranap inap. Staffing perawat primer dan perawat asosiet dirasa cukup memadai meskipun belum sesuai dengan kebutuhan yang sesungguhnya. Hasil supervisi rekam medis terbuka menunjukkan ruang ICU mencapai hasil diatas $90 \%$. Penilaian supervisi rekam medis terbuka salah satunya adalah format POC, akan tetapi masih sebatas ada atau tidak saja. Monitoring evaluasi POC belum kepada kualitas dan kesinambungan asuhan keperawatan mulai dari pengkajian, diagnosa, perencanaan, implementasi hingga evaluasi asuhan keperawatan.

Komite Keperawatan berperan merencanakan kredensial bagi seluruh perawat. Pelaksanaan kredensialing berada dibawah tanggung jawab subkomite kredensial. Kredensial menjamin ketersediaan perawat sesuai kompetensi dan kewenangan klinis berdasarkan standar MAKP.

Kepala ruangan berperan dalam pencanaan kebutuhan tenaga, penyusunan jadwal bulanan dan ketersediaan PAK (Panduan Asauhan Keperawatan) serta SPO (Standar Prosedur Operasional). Kepala ruangan bersama clinical instructor (CI) merencanakan dan melaksanakan evaluasi mutu asuhan keperawatan. CI bertanggung jawab dalammemberikan bimbingan dan evaluasi impementasi MAKP. CI bersama dengan perawat primer mengevaluasi rekam medis berdasarkan instrumen evaluasi implementasi MAKP.

\section{Analisis Ishikawa}

Analisis terkait perencanaan asuhan keperawatan di ruang intensif anak menggunakan diagram Ishikawa berdasarkan beberapa komponen yaitu man, mathods, materials, machine, measurement dan environment. 


\section{Diagram 1 Ishikawa Method:}

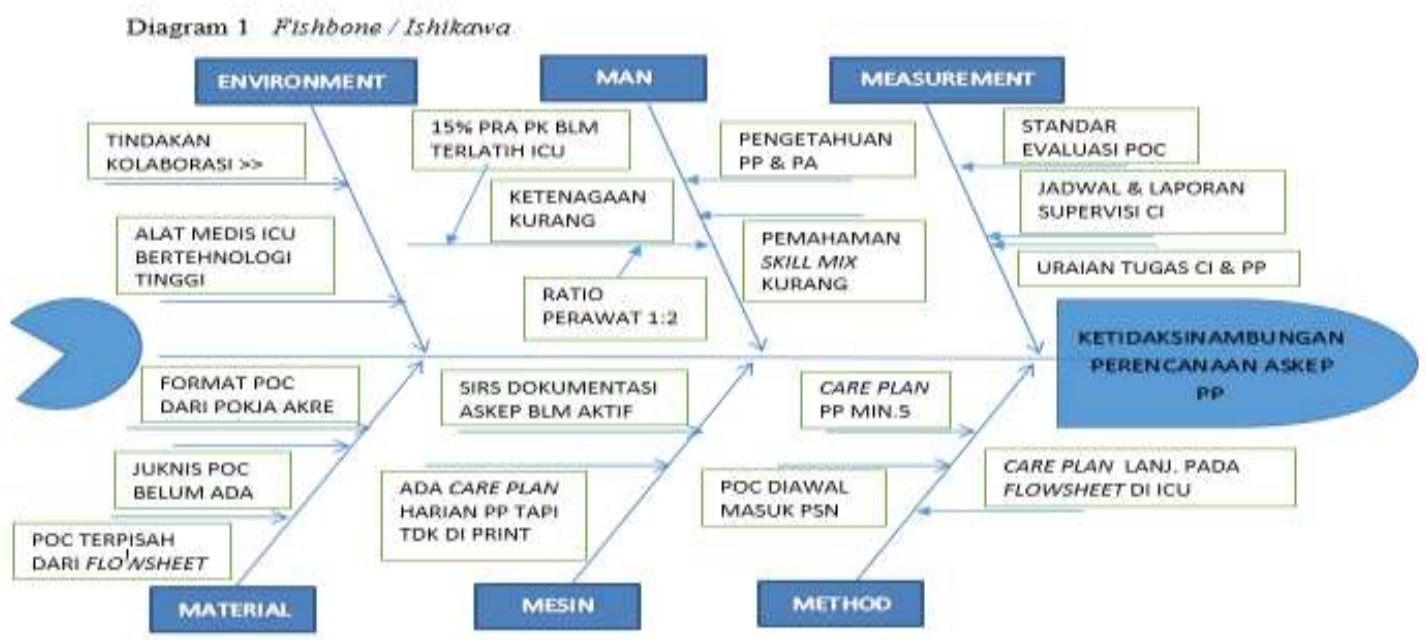

Tabel 2. Hubungan analisis Ishikawa dengan fungsi manajemen keperawatan.

\begin{aligned} \hline Faktor & Akar Masalah \\ \hline 1. Man & a. Ketenagaan perawat di ICU kurang memadai, \\ ditandai dengan : & 1) \\ & Ratio perawat dan pasien adalah $1: 2 \\ &$. tersier rationya adalah 1:1 berdasarkan \\ & kapasitas tempat tidur. \\ 2) & Perawat Pra PK sejumlah 15\% belum \\ & terlatih ICU. Mereka masih preseptee dari \\ & PK I. Sehingga belum dapat mandiri \\ & melakukan asuhan perawatan kritis. \end{aligned}

b. Pengetahuan tentang MAKP bagi perawat primer dan perawat pelaksana/asosiet belum merata. sehingga menimbulkan masalah/gap dalam pelaksanaannya.

c. Pemahaman tentangskill mix pada penjadwalan masih kurang sehingga perawat sering bertukar jadwal.

2. Methods

a. Sosialisasi tidak tertulis dari Bidang keperawatan menyatakan nursing care plan perawat primerdi ICU minimal berfokus pada 5 prioritas masalah pasien dan dilakukan secara komprehensif.

b. Sosialisasi POC selama ini adalah POC dicatat pada awal masuk pasien baru saja.

c. Penambahan nursing care plan berdasarkan assesmen lanjutan tidak didokumentasikan pada lembar POCpasien.

3. Machine a. Rumah sakit belum menggunakan sistem informasi tehnologi komputer. Namun sudah ada rencana dan sedang dalam proses pengadaan.

b. Ada dokumentasi perencanaan harian perawat primer dikomputer ruangan tetapi tidak dicetak. Dokumentasi ini sebagai media serah terima antara shift namun tidak terintegrasi dengan POC.

4.Material

a. Lembar POC bukan berasal dari Bidang keperawatan tetapi dari pokja ARK (Akses ke Rumah Sakit dan Kontinuitas Pelayanan)Standar Nasional Akreditasi Rumah Sakit (SNARS).

b. Petunjuk tehnik pengisian format POC belum ada.
Fungsi Manajemen

a. Staffing oleh kepala ruangan yaitu pengajuan tenaga perawat bagi ICU ditambahkan sesuai kebutuhan.

b. Staffing oleh Bidang keperawatan terkait rotasi \& rekruitmen.

c. Actuating oleh Kepala ruang dengan sosialisasi tentang MAKP dan skill mix.

d. Perencanaan Bidang keperawatanterkait pelatihan MAKP.

Fungsi pengarahan dan pengendalian dari Bidang keperawatan.

a. Supervisi proses pengadaan SIRS asuhan keperawatan dari Bidang keperawatan sudah berjalan.

b. Evaluasi dari Kepala ruang tentang sistempelaporan terintegrasi ke POC

Koordinasi oleh Bidang Keperawatan kepada bidang terkait mengenai penggunaan lembar POC. 
c. Lembar POC terpisah dari flowsheet harian pasien sehingga data di POC tidak selaluupdate.

5.Measure-ment a. Standar evaluasi penilaian POC masih sebatas ada atau tidak. Evaluasi belum berfokus pada kualitas.

b. Belum ada jadwal dan laporan supervisi CI terkait pelaksanaan asuhan keperawatan primer.

c. Uraian tugas CI sebagai penanggung jawab asuhan keparawatan primer di ruangan belum terintegrasi dalam Panduan MAKP terbaru (tahun 2017).

6.Environ-ment

Faktor penyebab lain yang cukup menyita waktu perawat sehingga mengganggu kualitas asuhan keperawatan pasien adalah:

a. Sarana dan fasilitas ICU mencakup alat-alat medis yang kompleks

b. Tindakan delegasi dan kolaborasi cukup tinggi di ruang ICU.
Pengendalian Bidang Keperawatan terkait evaluasi kesinambungan POC dan evaluasi uraian tugas $\mathrm{CI} /$ perawat primer.

a. Perencanaan Kepala ruang untuk pelatihan alat medis yang dipakai di ICU

b. Perencanaan Bidang keperawatan terkait pengembangan staf ICU.

\section{Pembahasan}

Lembar POC adalah lembar terintegrasi yang terdiri dari masalah yang ditemukan, rencana perawatan, target waktu dan target penyelesaian masalah, tanggal teratasi, Discharge Planning, dan tanda tangan DPJP serta PPA (Profesional Pemberi Asuhan) lainnya. Lembaran ini diisi oleh DPJP dan semua PPA interdisiplin yang ikut berkontribusi merawat satu pasien. Lembaran ini diharapkan dapat mengakomodir asuhan pasien secara komprehensif dan sesuai dengan standar akreditasi. POC bisa menjadi media untuk koordinasi interdisiplin PPA sehingga dapat menghindari perencanaan yang tumpang tindih antar disiplin (KARS, 2018).

\section{Fungsi Manajemen dalam mengoptimalkan POC adalah antara lain : \\ a. Perencanaan \\ 1) Kepala Ruangan.}

Perencanaan tenaga keperawatan pada level kepala ruangan meliputi orientasi tenaga keperawatan baru, proses hands on perawat baru dan preseptorship

(Hariyati,2014).
Perencanaan oleh kepala ruangan mencakup harian, mingguan dan bulanan. Rencana harian kepala ruangan yaitu berkoordinasi dengan perawat primer terkait pelayanan asuhan keperawatan pasien. Kepala ruang dapat sebagai nara sumber utama atau konsultan perawat primer.Hasil analisisIshikawa komponen environment pada diagram 1 menunjukkan bahwaKepala ruang perlu membuat rencana tahunan berhubungan dengan pelatihan pemakaian alat-alat medis di ICU. Pelatihan ini menjadi bagian dari pengembangan kompetensi dan keterampilan staf perawat baru.

2) Komite Keperawatan.

Kredensial keperawatan merupakan proses evaluasi terhadap tenaga keperawatan untuk menentukan kelayakan pemberian Kewenangan Klinis (PMK RI No. 49 tahun 2013). Kredensialing adalah akuntabilitas profesi keperawatan yang menunjukkan kesiapan seseorang sebagai profesi untuk memberikan pelayanan profesional kepada klien (Hariyati, 2016). Fungsi perencanaan Komite keperawatan yaitu menyusun 
perencanaan pelaksanaan kredensial seluruh perawat sehingga menjamin ketersediaan tenaga keperawatan sesuai dengan kewenangan klinis.

3). Bidang Keperawatan.

Perencanaan Bidang keperawatan dibuat sesuai dengan visi dan misi, filosofi, kebijakan, prosedur, peraturan serta perencanaan strategis organisasi (Marquis \& Huston, 2013). Perencanaan sebagai upaya memutuskan apa yang akan dilakukan, siapa yang melakukan, bagaimana, kapan dan dimana hal tersebut akan dilakukan. Perencanaan adalah suatu proses memulai dengan sasaran, batasan strategi, kebijakan dan rencana detail untuk mencapainya (Swanburg, 2000).

Perencanaan di Bidang keperawatan terkait sumber daya manusia dalam diagram 1 diatas adalah merencanakan dan membuat anggaran untukpelatihan MAKP dan pelatihan penggunaan alat-alat medis di ICU. Pelatihan MAKP dapat meningkatkan pengetahuan seluruh perawat tentang asuhan keperawatan primer dan kewenangan klinis.

\section{b. Organisasi}

Pada fungsi organisasisi, Kepala ruang mengorganisasikan dan menyusun struktur organisasi yang terdiri dari Kepala Ruang, CI (clinical instruktur), Perawat Primer (PP), Perawat asosiet/pelaksana dan penanggung jawab shift sesuai dengan kompetensi masing-masing.

Fungsi organisasi di Bidang Keperawatan dikaitkan dengan prinsip bahwa semua orang harus mengetahui apa pekerjaannya. Dalam pengorganisasian dibentuk struktur formal mengacu pada prinsip rumusan arah tujuan jelas, ada pembagian kerja, pendelegasian dan rentang kendali, pengawasan berjenjang, koordinasi serta kesatuan perintah dan tanggung jawab (Marquis \& Huston, 2013). Fase ini kegiatannya meliputi pengorganisasian struktur dan tugas organisasi serta diskripsi tugas dalam Metode Asuhan Keperawatan Primer (MAKP).

Fungsi organisasi tidak muncul dalam akar masalah pada tabel 2.Hasil observasi dokumen menunjukkan kelengkapan dari struktur, uraian tugas dan kewenangan klinis perawat. Hal ini menandakan baik Kepala ruang dan Bidang Keperawatan sudah melakukan fungsi organisasi dengan baik.

\section{c. Staffing/Kepersonaliaan}

1). Kepala Ruangan.

Pada fungsi staffing, kepala ruangan membuat jadwal dinas harian dan bulanan. Jadwal ruangan disusun berdasarkan klasifikasi pasien dengan komposisi disesuaikan dengan jam perawatan per pasien (HPPD), total paid hour, skill mix dan jumlah tenaga keperawatan yang dimiliki (Hariyati,2014). Fungsi staffingdari kepala ruangan untuk mengatasi masalah sumber daya manusia menurut diagram 1 diatasadalah pengajuan penambahan ketenagaan perawat di ruang ICU. Perhitungan ketenagaan meliputi jumlah dan kriteria kompetensi yang sudahdisesuaikan dengankebutuhan ruang ICU.

Ketenagaan yang kurang memadai akan mempengaruhi beban kerja perawat. Beban kerja merupakan variabel yang harus diperhitungkan dalam staffing(Min \& Scott, 2016; 
Trettene et al., 2017). Beban kerja tinggi mempengaruhi kualitas dokumentasi keperawatan (Siswanto, Hariyati, \& Sukihananto, 2013).

Penambahan ketenagaan perawat tidak dapat diperoleh langsung karena memerlukan perencanaan jangka panjang mencakup banyak aspek. Oleh sebab itu Kepala ruang dapat menerapkan beberapa strategi dalam staffing agar pelayanan keperawatan dapat berjalan sesuai standar. Staffing dapat berupa pengelolaan dalam penyusunan jadwal dinas, pengembangan staf yang berkelanjutan dan pelatihan(Cherry \& Jacob, 2014). Jadwal dinas perawat dapat dibuat dengan sistem skill mix untuk mengatasi kesenjangan kompetensi yang dimiliki. Sedangkan pengembangan staf yang berkelanjutan dapat dilakukan melalui metode mentorship dan preceptorship. Staffing akan lebih efektif apabila disertai dengan leadership yang baik (Cherry \& Jacob, 2014). Sehingga budaya bertukar jadwal dapat dihindari atau ditekan.

\section{2). Bidang Keperawatan.}

Staffing merupakan fase penting karena memastikan tersedianya staf yang profesional dan kompeten. Perawat manajer pada level bidang keperawatan berperan dalam merekrut, memilih, memberikan orientasi dan meningkatkan perkembangan individu untuk dapat mencapai tujuan organisasi (Marquis \& Huston, 2013).

Staffingoleh Bidang keperawatan menuruttabel 2diatas yaitu terkait rotasi dan rekruitmen. Berdasarkan hasil wawancara, Bidang keperawatan melakukan rotasi untuk mengatasi kesenjangan kompetensi perawat di ruang rawat inap. Perawat ICU di rotasi ke rawat inap dan memperoleh promosi menjadi clinical instructure atau penanggung jawab shift. Kelemahannya Bidang keperawatan merotasi perawat ICU ke unit lain tanpa kaderisasi sebelumnya. Pengganti perawat ICU yang dirotasi merupakan perawat baru (PraPK dan PK 1). Masalah lain terkait ketenagaan bagi Bidang Keperawatan adalah kebijakan rumah sakit bahwa rekruitmen karyawan baru direncanakan tahun depan. Oleh sebab itu staffing di Bidang keperawatan dalam jangka pendek adalah pengembangan kompetensi perawat melalui sosialisasi dan pelatihan sesuai kebutuhan.

\section{d. Pengarahan / Actuating}

1). Kepala Ruangan.

Di Rumah Sakit Ibu dan Anak Jakarta, Kepala ruang berfokus pada pelayanan dan pengelolaan ruangan, sedangkan untuk manajemen asuhan keperawatan lebih banyak didelegasikan kepada CI ruangan. CI ruangan bertugas memberikan bimbingan praktek klinik pada staf perawat, selain itu juga bertugas dalam pelaksanaan manajemen asuhan keperawatan di ruangan. Kepala ruang dan CIruangan bersama-sama mengarahkan perawat ruangan dalam memberikan asuhan keperawatan pada pasien.

Analisis Ishikawa pada diagram 1 menunjukkan bahwa masalah sumber daya manusia terkait ketidaksinambungan nursing care plan adalah pengetahuan perawat primer dan perawat pelaksana tentang 
Metode Asuhan Keperawatan Primer (MAKP) masih belum optimal. Pelatihan MAKP belum merata diberikan kepada semua staf perawat.

Tabel 2 menunjukkan bahwa fungsi pengarahan kepala ruang dengan cara sosialisasi MAKP dapat mengurangi atau mencegah gap/masalah sebagai akibat kurang pengetahuan perawat tentang MAKP. Sosialisasi ini memberi pemahaman mengenai asuhan keperawatan primer, tugas dan tanggung jawab antara perawat primer dan perawat pelaksana.

Fungsi pengarahan lain dalam tabel 2diatas adalah terkait sosialisasi mengenai skill mix kepada staf perawat. Staf perawat diharapkan tidak berperilaku saling bertukar jadwal dinas tanpa memperhatikan komposisi ketenagaan dalam jadwal dinasyang sudah dibuat. Pelayanan asuhan keperawatan akan terganggu jika perawat yang bertugas dalam satu shift kompetensinya tidak seimbang, dalam arti bahwa ada satu shift yang terdiri dari perawat senior sedang shift berikutnya lebih banyak perawat baru. Penelitian mengatakan bahwa skill mix sangat berpengaruh terhadap mutu pelayanan, angka kematian dan jumlah kunjungan pasien (Aiken et al., 2017; He, Staggs, Beringer, \& Dunton, 2016; Staggs, Olds, Cramer, \& Shorr, 2017).

2). Bidang Keperawatan.

Bidang Keperawatan mengarahkan tenaga perawat agar berperilaku sesuai dengan tujuan organisasi. Komponen pengarahan meliputi memotivasi, membina komunikasi, penanganan konflik, memfasilitasi kerjasama, negosiasi, delegasi dan supervisi (Marquis \& Huston, 2013).
Sosialisasi asuhan keperawatan oleh Bidang keperawatan menyatakan bahwa perawat primer dalam membuat nursing care plan cukup lima masalah yang berfokus kepada kebutuhan prioritas pasien. Penetapan jumlah diagnosa/masalah ini bertujuan agar perawat berfokus pada lima prioritas masalah tersebut dan dianggap mampu tata laksana. Asuhan keperawatan anak di ICU sangat kompleks sehingga jika hanya lima diagnosa saja tentunya belum dapat memenuhi kebutuhan pasien. Pengkajian lanjutan berikutnya, nursing care plan berkembang lebih dari lima masalah didalamflowsheet pasien. POC tidak diperbaharui lagi karena ketidakpahaman perawat primer mengenai pentingnya lembar POC. Celah inilah yang berkontribusi menyebabkan ketidaksinambungan POC dengan flowsheet harian.

Standar 3 dari ARK (Akses ke Rumah Sakit Dan Kontinuitas Pelayanan) menjelaskan tentang kesinambungan asuhan pasien. Asuhan pasien di rumah sakit dimulai dari admisi, keluar pulang, atau pindah melibatkan berbagai profesional pemberi asuhan (PPA), unit kerja, dan MPP (Manajer Pelayanan Pasien). Kesinambungan pelayanan berjalan baik jika semua pemberi pelayanan mempunyai informasi yang dibutuhkan tentang kondisi kesehatan pasien terkini dan sebelumnya agar dapat dibuat keputusan yang tepat (KARS, 2018).

Lembar POC merupakan produk dari pokja ARK saat proses akreditasi rumah sakit berlangsung, akan tetapi kemudian tidak termonitor dengan baik karena Manajer Pelayanan Pasien (MPP) belum terbentuk. Oleh 
sebab itu Bidang keperawatan perlu berkoordinasi pada bidang terkait dan interprofesional lainnya untuk evaluasi efektifitas lembar POC. Lembar POC dibuat bertujuan sebagai media komunikasi yang terintegrasi antar Profesional Pemberi Asuhan (PPA) pada setiap pasien. Sehingga masing-masing PPA dapat saling mendukung dalam membuat perencanaan asuhan pasien. Dengan demikian tujuan pelayanan asuhan pasien yang berkesinambungan secara interprofesional dapat tercapai.

Bidang keperawatan berperan juga dalam meningkatkan pemahaman perawat melalui sosialisasi terkait lembar POC pada seluruh perawat khususnya perawat primer. Sosialisasi mencakup tentang petunjuk tehnis pengisian, kuantitas dan kualitas nursing care plan yang disusun oleh perawat primer serta pembaharuannya secara berkelanjutan.

\section{e. Pengendalian}

1). Kepala Ruangan.

Dalam fungsi pengendalian, Kepala ruang dapat mengevaluasi kualitas asuhan keperawatan dengan banyak tools, misalnya dari tingkat kepuasan pasien/keluarga, kepuasan kerja, kelengkapan status/file dan pencapaian indikator kinerja ICU (angka dekubitus, angka infeksi nasokomial, angka VAP, angka cidera restrain/jatuh, angka ekstubasi tidak terencana dan lain-lain). Keseluruhan capaian kinerja ruangan merupakan ukuran keberhasilan dari pelaksanaan asuhan keperawatan pasien.

2). Bidang Keperawatan.

Pada fase ini kinerja diukur menggunakan standart yang telah ditentukan sebelumnya dan tindakan diambil untuk mengkoreksi ketidakcocokan antara standar dan kinerja yang sebenarnya (Marquis \& Huston, 2013). Analisis Ishikawa pada diagram 1 menghasilkan penguatan pada fungsi pengendalian bidang keperawatan. Pengendalian terkait evaluasi kesinambungan POC, evaluasi uraian tugas perawat primer dan evaluasi laporan supervisi dari Kepala ruang dan CI ruangan.

\section{Kesimpulan dan Rekomendasi}

Manajer keperawatan di rumah sakit berfungsi sebagai penggerak, pembimbing dan pemberi motivasi bagi seluruh staf perawat. Perawat manajer dengan mengimplementasikan fungsi manajemen keperawatan dapat mengoptimalkan kualitas dokumentasi perencanaan asuhan keperawatan. Perawat manajer yang dimaksud adalahberjenjang dari Kepala ruang hingga Bidang Keperawatan. Kepala ruang dan Bidang Keperawatan perlu melakukan penguatan pada fungsi manajemen khususnya fungsi pengarahan dan fungsi pengendalian.

Fungsi pengarahan Kepala Ruang perlu ditingkatkan melalui sosialisasi tentang metode asuhan keperawatan primer serta supervisi terhadap perawat primer saat dokumentasidilembar POC. Kepala ruang juga direkomendasikan untuk mengajukan pengadaan papan berjalan untuk setiap rekam medis di ruang ICU agar lembar POC, flowsheet dan Catatan Perkembangan Pasien Terintegrasi (CPPT) menjadi satu kesatuan yg utuh tidak terpisah-pisah. 
Bidang Keperawatan berperan dalam review atau revisi standar penilaian saat evaluasi lembar POC dan mengevaluasi kembali uraian tugas perawat primer. Standar penilaian evaluasi rekam medis POC perlu diperluas indikatornya mencakup perencanaan awal masuk, asessmen lanjutan dan rencana pemulangan pasien. Uraian tugas perawat primer juga perlu dilakukanreview dengan penambahan tugas yaitu melakukan pengkajian lanjutan selama pasien dirawat.Selain itu Bidang keperawatan juga direkomendasikan untuk mengembangkan sistem penilaian kinerja Ongoing Professional Practice Evaluation (OPPE). Sehingga fungsi pengarahan dan pengendalian dapat lebih maksimal pelaksanaannya.

\section{Daftar Pustaka}

Aiken, L. H., Sloane, D., Griffiths, P., Rafferty, A. M., Bruyneel, L., McHugh, M., ... Van Achterberg, T. (2017). Nursing skill mix in European hospitals: Crosssectional study of the association with mortality, patient ratings, and quality of care. BMJ Quality and Safety, 26(7), 559-568. https://doi.org/10.1136/bmjqs2016-005567

Asamani, J. A., Amenorpe, F. D., Babanawo, F., \& Ofei, A. M. A. (2014). Nursing documentation of inpatient care in eastern Ghana. British Journal of Nursing, 23(1), 48-54.

https://doi.org/10.12968/bjon.201 4.23.1.48

Cherry, B., \& Jacob, S. R. (2014). Contempory Nursing: Issues, Trends, \& Management. Mosby, an Inprint of Elsevier Inc.
https://doi.org/10.1017/CB097811 07415324.004

Choi, M., \& De Gagne, J. C. (2016).

Autonomy of nurse practitioners in primary care: An integrative review. Journal of the American Association of Nurse Practitioners, 28(3), 170-174.

https://doi.org/10.1002/23276924.12288

Cox Sullivan, S., Norris, M. R., Brown, L. M., \& Scott, K. J. (2017). Nurse manager perspective of staff participation in unit level shared governance. Journal of Nursing Management, 25(8), 624-631. https://doi.org/10.1111/jonm.1250 0

Hastuti, A. T. (2014). Hubungan Persepsi Perawat Pelaksana Tentang kemampuan Supervisi Kepala Ruang Dengan Kinerja Perawat Di Instalasi Rawat Inap Rumah Sakit Umum Daerah Kota Semarang, 7(2), 118-129.

He, J., Staggs, V., Beringer, S., \& Dunton, N. (2016). Nurse staffing and patient outcomes: A longitudinal study on trend and seasonality. BMC Nursing, 15(60), 1-10. https://doi.org/10.1186/s12912016-0181-3

Heale, R., Dickieson, P., Carter, L., \& Wenghofer, E. F. (2014). Nurse practitioners' perceptions of interprofessional team functioning with implications for nurse managers. Journal of Nursing Management, 22(7), 924930.

https://doi.org/10.1111/jonm.1205 4

KARS. (2018). Standar Nasional Akreditasi Rumah Sakit 
(SNARS) Edisi 1.

https://doi.org/362.11

Kozier, B., Erb, G., Berman, A., \&

Synder, S. (2016). Fundamentals

of Nursing Concept, Process and

Practice.

Marquis, Bessie. L \& Huston, C. J.

(2015). Leadership roles and

management functions in nursing:

theory and application.

Marquis, B., \& Huston, C. (2013).

Leadership Roles and Management

Function in Nursing. Journal of

Chemical Information and

Modeling (Vol. 53).

https://doi.org/10.1017/CB097811

07415324.004

Min, A., \& Scott, L. D. (2016).

Evaluating nursing hours per patient day as a nurse staffing measure. Journal of Nursing Management, 24(4), 439-448. https://doi.org/10.1111/jonm.1234 7

Owens, A. (2014). Comparing Nurse

Job Satisfaction Between

Different Work Environments.

Comparing Nurse Job Satisfaction

Between Different Work

Environments, 62 p-62 p 1p.

Retrieved from

http://search.ebscohost.com/login

.aspx ?direct $=$ true\&db $=\operatorname{cin} 20 \& \mathrm{~A}$

$\mathrm{N}=109776554 \&$ site $=$ ehost-live

Siswanto, L. M. H., Hariyati, R. T. S.,

\& Sukihananto. (2013). Faktor-

faktor yang berhubungan dengan

kelengkapan pendokumentasian

asuhan keperawatan. Jurnal

Keperawatan Indonesia, 16(2),

77-84. https://doi.org/pISSN

1410-4490, eISSN 2354-9203

Staggs, V., Olds, D., Cramer, E., \&

Shorr, R. (2017). Nursing Skill

Mix, Nurse Staffing Level, and

Physical Restraint Use in US
Hospitals: a Longitudinal Study. Journal of General Internal Medicine, 32(1), 35-41. https://doi.org/10.1007/s11606016-3830-z

Trettene, A. D. ., Bertoncello, F. . M., Razera, A. . R., Prado, P. C., Bom, G. C., \& Kostrisch, L. M. V. (2017). Sizing of nursing staff associated with self-care promotion in a pediatric semiintensive care unit. Revista Brasileira de Terapia Intensiva, 29(2), 171-179.

https://doi.org/10.5935/0103507X.20170027

Wirawan, E. agung, Novitasari, D., \& Wijayanti, F. (2013). Hubungan Antara Supervisi Kepala Ruang Dengan Pendokumentasian Asuhan Keperawatan di Rumah Sakit Umum Daerah Ambarawa. Jurnal Manajemen Keperawatan, $1(1), 1-6$. 